DOI: 10.36695/2219-5521.2.2020.98

удк $341.9: 347.82$

\title{
Д.Р. ДОРОШЕНКО
}

Дмитро Романович Дорошенко, студент магістратури Київського університету права НАН України*

\section{ОКРЕМІ ПИТАННЯ РЕГУЛЮВАННЯ МІЖНАРОДНИХ ПОЛЬОТІВ ЗАКОНОДАВСТВОМ УКРАЇНИ}

Постановка проблеми. На сучасному етапі розвитку транспортного сполучення питання міжнародних польотів набуває особливого значення у контексті можливості швидкого подолання за їх допомогою великих відстаней. Їх важливість зумовила необхідність формування спеціального міжнародно-правового регулювання, яке б гарантувало безпечність польотів. Враховуючи велике значення міжнародних польотів у світі, можна зазначити, що їх роль $є$ важливою і для України як суб'єкта міжнародного права та учасника міжнародних відносин. Вироблені норми міжнародного повітряного права здійснили вплив і на формування національного законодавства у цій сфері, зокрема і в Україні. 3 урахуванням великого значення, яке має здійснення міжнародних польотів, необхідно дослідити особливості їх врегулювання законодавством України.

Аналіз останніх досліджень і публікацій. Зазначимо, що досліджуване питання порушувалось у наукових роботах іноземних та вітчизняних дослідників, зокрема: А.С. Бичкова, В.Д. Бордунова, А.С. Васильєва, О.М. Григорова, А.В. Линькова, О.В. Мякоти, О.В. Нестерука, О.П. Радчука, В.В. Семеняки, Т.Л. Сироїд, А.О. Собакарь, Ю.С. Шемшученка та інших.

Формулювання мети статті. Метою статті є аналіз національного законодавства України у питанні регулювання міжнародних польотів та питань, пов'язаних із здійсненням відповідних польотів.

Виклад основного матеріалу. Насамперед зазначимо, яким чином законодавство України визначає поняття «міжнародний політ». Відповідно до Наказу Державної служби України з нагляду за забезпеченням безпеки авіації Міністерства оборони України «Про затвердження Правил надання експлуатантам дозволів на виліт з аеропортів України та приліт до аеропортів України» № 897/703 від 2005 р. міжнародний політ це політ, який складається 3 одного або декількох міжнародних етапів польоту ${ }^{1}$.

Аналогічне визначення закріплено і в Наказі Державної авіаційної служби України «Про затвердження Авіаційних правил України «Технічні вимоги та адміністративні процедури щодо моніторингу викидів (емісіï) експлуатантами цивільних повітряних суден» № 1001 від 2019 р., згідно $з$ яким міжнародний політ - це політ, що складається з одного або декількох міжнародних етапів польоту2

Однак слід підкреслити, що у законодавстві України містяться й інші визначення міжнародного польоту. Так, відповідно до Наказу Міністерства оборони України «Про затвердження Правил штурманського забезпечення польотів державної авіації України» № 100 від 2016 р. міжнародний політ визначено як політ, пов'язаний із перетинанням повітряними суднами державного кордону України та іншої держави, або політ, який виконується в повітряному просторі іншої держави (інших держав)3. Отже, не зважаючи на закріплення подібних визначень у двох різних правових актах, все ж спостерігаємо відсутність певної усталеності у розумінні поняття «міжнародний політ», що може сприйматись як наявність певної законодавчої недосконалості у відповідному питанні. На нашу думку, для систематизації правових підходів до визначення досліджуваного терміна доцільно внести його до положень Повітряного кодексу України як основоположного законодавчого акта у сфері повітряного права $з$ тим, щоб уніфікувати підходи до тлумачення відповідного терміна та уникнути майбутніх суперечностей при розгляді питань, пов'язаних із міжнародними польотами.

Проаналізувавши вищенаведені визначення, вважаємо, що найбільш точним є визначення, наведене в Наказі Міністерства оборони України № 100 від 2016 р., адже у ньому найповнішою мірою розкрито сутність міжнародних польотів, зокрема враховано факт перетину повітряним судном державного кордону будьякої держави, зокрема й України. Тому для подальшого дослідження вважаємо доречним застосовувати саме це визначення.

() Д.Р. Дорошенко, 2020

* Dmytro Doroshenko, student of II year of Master's degree division of Kyiv University of Law of the NAS of Ukraine 
У контексті теми дослідження, яка пов'язана із окремими питаннями міжнародних польотів, вважаємо за доцільне розглянути низку актуальних питань, які виникають у контексті правового регулювання міжнародних польотів нормами законодавства України. Передусім із поняттям міжнародного польоту тісно пов'язане поняття правового режиму міжнародного польоту. Він являє собою сукупність юридичних норм, які визначають права та обов'язки держав щодо повітряного простору, його використання, порядок повітряних перевезень, правовий статус повітряних суден і членів екіпажу, вантажу та пасажирів ${ }^{4}$. Зазначимо, що режим повітряного простору та міжнародних польотів над територією кожної держави регулюється ï національним законодавством та міжнародними договорами, які вона уклала з іншими державами та двосторонній/багатосторонній основі.

Наступним важливим питанням, яке виникає у контексті розгляду міжнародних польотів, $є$ особливості правового регулювання міжнародних авіаперевезень законодавством України. Розглядаючи його, зупинимо увагу насамперед на Повітряному кодексі України від 2011 р., який встановлює правові основи діяльності в галузі авіації. Державне регулювання діяльності в галузі авіації та використання повітряного простору України спрямоване на гарантування безпеки авіації, забезпечення інтересів держави, національної безпеки та потреб суспільства і економіки у повітряних перевезеннях та авіаційних роботах 5 . Як доречно зазначає український науковець О.П. Радчук: «Повітряний кодекс України встановив таке поняття, як суспільно важливі повітряні перевезення та виходить із того, що Україні належить повний і виключний суверенітет над повітряним простором України. У той же час Україна несе повну відповідальність за виконання міжнародних зобов'язань, що взяла на себе шляхом підписання цілої низки міжнародних конвенцій. Рішення про визнання певної повітряної лінії як суспільно важливої приймає Уповноважений орган з питань цивільної авіації. При цьому враховуються важливість повітряної лінії для міста або регіону, а тому перевізник повинен безперервно та регулярно здійснювати авіаперевезення за дотримання певних обсягів та рівня оплати. На першому етапі дається оголошення про таку лінію та самі авіаперевізники приймають рішення про виконання такої роботи. Якщо жоден не погоджується на встановлені умови, то може бути оголошений відкритий конкурс для українських та для іноземних авіаперевізників для визначення тих, хто буде виконувати такі авіаперевезення» 6 .

В основу врегулювання міжнародних польотів покладено розуміння повітряного простору держави. Відповідно до п. 81 ст. 1 Повітряного кодексу України повітряний простір України - частина повітряної сфери, розташована над суходолом і водною територією України, у тому числі над її територіальними водами (територіальним морем), і обмежена вертикальною поверхнею, що проходить по лінії державного кордону України‥ У контексті цього слід звернути увагу на Конвенцію про міжнародну цивільну авіацію (Чиказьку конвенцію) від 1944 р., ратифіковану Україною у 1992 р., у положеннях якої зазначено, що Договірні держави визнають, що кожна держава володіє повним і винятковим суверенітетом над повітряним простором над своєю територією. Крім того, у Конвенції зазначено, що під територією держави розуміються сухопутні території і прилеглі до них територіальні води, які знаходяться під суверенітетом даної держави ${ }^{8,9}$. Виходячи із порівняння положення щодо державного суверенітету та повітряного простору, закріпленого у Повітряному кодексі та Чиказькій конвенції, можна стверджувати, що у зазначених нормах Повітряного кодексу Україна імплементувала відповідні норми Конвенції про міжнародну цивільну авіацію10.

Однак, беручи до уваги важливість визначення суверенітету держави над повітряним простором, ми стикаємося із наступною актуальною проблемою, яка полягає у визначенні такого простору. Слід наголосити, що у законодавстві України, так само як і у міжнародному праві, не існує нормативного закріплення верхньої межі повітряного простору, на яку поширюється територіальний суверенітет держави. Найпоширенішою в українській доктрині $є$ думка про визначення межі між повітряним і космічним просторами на висоті мінімальних штучних супутників Землі (приблизно 100-110 км над рівнем океану). Такої думки дотримуються такі вітчизняні науковці: Г.М. Даниленко, О.В. Мякота, С.М. Перепьолкін, В.В. Семеняка, О.В. Столярський, Л.А. Філяніна та інші.

Однак існують й інші погляди на відповідне питання. Так, наприклад, згідно з класифікацією Військово-повітряних сил США, космічним польотом вважають політ, висота якого перевищує 50 миль (80 км 467 м) над рівнем океану. При цьому фахівці NASA визначають кордон космічного простору на висоті 122 км. Разом із тим технічний розрахунок вчених з Університету Калгарі (Канада) свідчить, що межа між земною атмосферою і відкритим космосом проходить на висоті 118 км від поверхні Землі11. Таким чином, питання делімітації повітряного простору є актуальним і для українського законодавства, i для міжнародного права загалом. Відповідне питання має бути регламентоване на міжнародно-правовому рівні та імплементоване у національне законодавство держав з метою уникнення суперечностей у відповідному питанні. Ми поділяємо думку вітчизняних науковців щодо встановлення межі суверенітету держав над повітряним простором приблизно у 100-110 км над рівнем океану, адже вважаємо, що така усталена межа, яка все ж прийнята більшістю держав, має бути регламентована на міжнародно-правовому рівні та стати обов'язковою для держав світу шляхом прийняття відповідного правового акта. На нашу думку, відповідна уніфікація у підході до розуміння встановлення межі між повітряним та космічним простором у 100-110 км над рівнем океану у подальшому закладе міцніші засади співробітництва держав у відповідній галузі без будь-яких суперечностей та стане попередженням для виникнення конфліктів, пов'язаних із відмінностями держав у підходах до розуміння делімітації повітряного та космічного просторів.

Важливим питанням у галузі міжнародних польотів є дослідження особливостей авіації, що є широким за змістом поняттям, яке, за визначенням англійського дослідника Дж.Д. Андерсона, включає у себе будь-яку діяльність, пов'язану з механічним польотом та авіаційною промисловістю ${ }^{12}$. Тобто виходячи із наведеного визначення можна стверджувати, що міжнародні польоти є складовою частиною авіації. Авіацію прийнято 
поділяти на дві категорії: цивільну та державну авіацію. Згідно зі ст. 4 Повітряного кодексу України, цивільна авіація задовольняє потреби держави і громадян у повітряних перевезеннях і авіаційних роботах та виконанні польотів у приватних цілях і поділяється на комерційну авіацію та авіацію загального призначення. Державна авіація використовує повітряні судна з метою забезпечення національної безпеки і оборони держави та захисту населення, які покладаються на Збройні Сили України, інші військові формування, утворені відповідно до законів України, органи Національної поліції, спеціально уповноважений центральний орган виконавчої влади з питань цивільного захисту, органи охорони державного кордону України, органи доходів і зборів ${ }^{13}$.

Важливим питанням у контексті розгляду міжнародних польотів є забезпечення безпеки під час їхнього здійснення. Український науковець А.О. Собакарь, посилаючись на дані Міжнародної організації цивільної авіації, підкреслив: «Відносні показники рівня безпеки польотів у вітчизняній галузі цивільної авіації значно гірші від середніх загальносвітових показників» ${ }^{14}$. Виходячи із цього, можна стверджувати, що безпека цивільної авіації є актуальною проблемою для України. Зазначимо, що А.О. Собакарь вважає, що безпеку польотів на авіаційному транспорті доцільно визначати як стан захищеності елементів (суб'єктів) авіаційнотранспортної системи, діючих для задоволення потреб суспільства в авіаційних роботах та перевезеннях, при якому забезпечується своєчасне виявлення, запобігання і нейтралізація реальних та потенційних загроз безпеці польотів, а при їх наявності або виникненні виключається можливість заподіяння шкоди від них ${ }^{15}$.

Законодавство України містить окремі правові акти, спрямовані на врегулювання питання безпеки міжнародних польотів. Передусім відзначимо Наказ Державної служби України з нагляду за забезпеченням безпеки авіації «Про затвердження Положення про систему управління безпекою польотів на авіаційному транспорті» № 895 від 2005 р., положення якого спрямовані на визначення порядку організації робіт щодо попередження авіаційних подій, завдання та функції управління, органів, об'єктів та суб'єктів управління, встановлює форми контролю за виконанням робіт. Дія цього Положення поширюється на всіх суб'єктів цивільної авіації України незалежно від форм власності, у тому числі на організації та громадян, які здійснюють експлуатацію повітряних суден, виконання і забезпечення польотів та обслуговування повітряного руху на території України. Управління безпекою польотів у цивільній авіації виконує Державна служба України 3 нагляду за забезпеченням безпеки авіації16.

Водночас можемо зазначити, що не зважаючи на важливість питання безпеки міжнародних польотів для України, на сучасному етапі розвитку відповідному питанню не приділено достатньо уваги ні у законодавчих актах, ні на рівні практичного забезпечення безпеки. У цьому контексті доречно згадати Повітряний кодекс України, адже незважаючи на той факт, що він виступає основним правовим актом, що регулює діяльність користувачів повітряного простору України з метою задоволення інтересів України та іiі громадян і забезпечення безпеки авіації, в ньому лише передбачено розділ (XIII), присвячений захисту авіації від актів незаконного втручання, і взагалі проігноровано питання забезпечення безпеки польотів. На нашу думку, питання забезпечення безпеки міжнародних польотів заслуговує більшої уваги та має бути конкретизоване у законодавстві України. Не зважаючи на факт наявності Наказу Державної служби України з нагляду за забезпеченням безпеки авіації «Про затвердження Положення про систему управління безпекою польотів на авіаційному транспорті» № 895 від 2005 р., вважаємо, що його положень недостатньо. Крім того, цей наказ $\epsilon$ підзаконним нормативно-правовим актом, юридична сила якого є нижчою за силу закону або того ж Повітряного кодексу, в якому питання безпеки розкрито неналежним чином. 3 урахуванням всіх вищевикладених обставин вважаємо, що у відповідному напрямі мають бути прийняті більш суттєві кроки щодо правового регламентування безпеки польотів. Так, доречно прийняти окремий законодавчий акт, положення якого детально регламентували окремі аспекти, спрямовані на забезпечення безпеки міжнародних польотів. Зокрема, доцільно врегулювати питання технічного забезпечення міжнародних польотів, а також правового захисту осіб у випадку недодержання державою або авіакомпанією відповідних норм.

У цілому слід зазначити, що роль цивільної авіації у забезпеченні прискореного розвитку як регіональної, так і світової економіки зростає час від часу. Між тим, в Україні саме цій складовій регіональної комунікаційної мережі більше всього притаманні системні проблеми, серед яких слід виокремити відсутність регіональної інтеграції суб'єктів господарювання. Така проблема суттєво гальмує розвиток авіапромисловості та загалом стримує економічний розвиток регіонів і країни.

Висновки. Таким чином, можна стверджувати, що міжнародний політ являє собою політ, пов'язаний із перетином повітряними суднами державного кордону України та іншої держави, або політ, який виконується в повітряному просторі іншої держави (інших держав). Зазначимо, що незважаючи на імплементацію Україною приписів міжнародно-правових актів, тим не менш, у законодавстві все ще існують деякі прогалини щодо врегулювання питання міжнародних польотів, які потребують свого врегулювання, серед яких: делімітація повітряного простору; врегулювання питання безпеки міжнародних польотів; уніфікація підходів до визначення повітряного простору. Більше того, навіть на міжнародному рівні існують невирішені питання, зокрема щодо межі поширення державного суверенітету на повітряний простір, які ускладнюють подальше співробітництво держав.

3 урахуванням недостатньої правової та інституційної забезпеченості безпеки міжнародних польотів вважаємо доречним прийняти окремий закон, положення якого будуть врегульовувати окремі питання забезпечення безпеки, зокрема, передбачати дієві процедури та специфічні функції щодо забезпечення безпеки польотів на рівні різних органів управління з позиції реалізації та захисту права громадян на безпечне середовище, регулювання транспортної безпеки у системі національної безпеки, гарантування безпечності пасажирських та вантажних перевезень авіаційним транспортом, виконання вимог міжнародно-правових принципів і норм. 
1 Про затвердження Правил надання експлуатантам дозволів на виліт з аеропортів України та приліт до аеропортів України: наказ Державної служби України з нагляду за забезпеченням безпеки авіації Міністерства оборони України № $897 / 703$ від 28.11.2005 p. URL: https://zakon.rada.gov.ua/laws/show/z1572-05/ed20111003/find?text=\%CC\%B3\%E6\%ED\%E0\%F $0 \% \mathrm{EE} \% \mathrm{E} 4 \%$ $\mathrm{ED} \% \mathrm{E} \%$ E9+\%EF\%EЕ\%EB\%B3\%F2 (дата звернення: 29.11.2019).

2 Про затвердження Авіаційних правил України «Технічні вимоги та адміністративні процедури щодо моніторингу викидів (емісії) експлуатантами цивільних повітряних суден: наказ Державної авіаційної служби України № 1001 від 02.08 .2019 р. URL: https://zakon.rada.gov.ua/laws/show/z0962-19/ed20190802\#n27 (дата звернення: 29.11.2019).

3 Про затвердження Правил штурманського забезпечення польотів державної авіації України: наказ Міністерства оборони України № 100 від 23.02.2016 p. URL: https://zakon.rada.gov.ua/laws/show/z0418-16/ed20160223\#n32 (дата звернення: 29.11.2019).

4 Репецький В.М. Міжнародне публічне право. Київ: Знання, 2011. С. 294.

5 Повітряний кодекс України: Закон України № 3393-VI від 19.05.2011 p. URL: https://zakon.rada.gov.ua/laws/show/3393-17 (дата звернення: 29.11.2019).

6 Радчук О.П. Міжнародно-правове регулювання авіаційних перевезень. Форум права. 2015. № 2. С. 146.

7 Повітряний кодекс України: Закон України № 3393-VI від 19.05.2011 p. URL: https://zakon.rada.gov.ua/laws/show/3393-17 (дата звернення: 29.11.2019).

8 Статус Конвенції про міжнародну цивільну авіацію. URL: https://zakon.rada.gov.ua/laws/show/954_011 (дата звернення: 30.11.2019).

9 Конвенції про міжнародну цивільну авіацію від 07.12.1944 p. URL: https://zakon.rada.gov.ua/laws/main/995_038 (дата звернення: 30.11.2019).

10 Мякота О.В. Правове регулювання повітряного кордону України. URL: http://dspace.nlu.edu.ua/bitstream/123456789/ 11322/1/Mykota 153-159.pdf (дата звернення: 30.11.2019).

11 Нестерук О.В. Демілітаризовані та нейтралізовані території. URL: http://dspace.onua.edu.ua/bitstream/handle/11300/ 3991/Нестерук.pdf?sequence=1\&isAllowed=y (дата звернення: 30.11.2019).

12 John D. Anderson, Jr. Inventing Flight: The Wright Brothers and Their Predecessors, Maryland: The John Hopkins University Press, 2004. P. 22.

13 Повітряний кодекс України: Закон України № 3393-VI від 19.05.2011 p. URL: https://zakon.rada.gov.ua/laws/show/3393-17 (дата звернення: 29.11.2019).

14 Собакарь А.О. Безпека польотів на авіаційному транспорті: категоріально-правовий аналіз. Форум права. 2011. № 1. С. 932.

15 Там само.

16 Про затвердження Положення про систему управління безпекою польотів на авіаційному транспорті: наказ Державної служби України з нагляду за забезпеченням безпеки авіації № 895 від 25.11.2005 p. URL: https://zakon.rada.gov.ua/laws/main/ z1503-05 (дата звернення: 30.11.2019).

\section{Резюме}

Дорошенко Д.Р. Окремі питання регулювання міжнародних польотів законодавством України.

У статті розкриті особливості тлумачення поняття «міжнародні польоти» згідно із законодавством України та обгрунтовано думку про те, що відповідне визначення доцільно закріпити у положеннях Повітряного кодексу України. Крім того, проаналізовано поняття «правовий режим міжнародного польоту» та «повітряний простір України», зокрема, приділено увагу проблемам встановлення меж державного суверенітету над повітряним простором та розглянуто різні підходи до їх вирішення $\mathrm{i}$ обгрунтовано авторську позицію щодо цього явища.

У статті розкриваються особливості авіації та здійснено характеристику ії видів, які включають у себе цивільну та державну авіацію. Автором також розглянуто проблеми, наявні у законодавстві України у галузі безпеки міжнародних польотів та запропоновано можливі шляхи їх вирішення.

Ключові слова: міжнародні польоти, повітряний простір, безпека міжнародних польотів, правовий режим міжнародних польотів, Повітряний кодекс України.

\section{Резюме}

Дорошенко Д.Р. Отдельные вопросы регулирования международных полетов законодательством Украины.

В статье раскрыты особенности толкования понятия «международные полеты» в соответствии с законодательством Украины и обосновано мнение о том, что соответствующее определение целесообразно закрепить в положениях Воздушного кодекса Украины. Кроме того, проанализированы понятия «правовой режим международного полета» и «воздушное пространство Украины», в частности, уделено внимание проблемам установления границ государственного суверенитета над воздушным пространством и рассмотрены различные подходы к их решению, а также обоснованно авторскую позицию в отношении этого явления.

В статье также раскрываются особенности авиации и осуществлена характеристика ее видов, которые включают в себя гражданскую и государственную авиацию. Автором также рассмотрены проблемы, имеющиеся в законодательстве Украины в области безопасности международных полетов и предложены возможные пути их решения.

Ключевые слова: международные полеты, воздушное пространство, безопасность международных полетов, правовой режим международных полетов, Воздушный кодекс Украины.

\section{Summary}

Dmytro Doroshenko. Some issues of regulation of international flights by the legislation of Ukraine.

The article reveals the interpretation of the concept of "international flights" in accordance with the legislation of Ukraine and substantiates the opinion that it is advisable to fix the corresponding definition in the provisions of the Air Code of Ukraine. In addition, the concepts of "legal regime of international flight" and "airspace of Ukraine" are analyzed, in particular, attention is paid to the problems of establishing the boundaries of state sovereignty over airspace and various approaches to their solution and the author's position with respect to this phenomenon are considered.

In addition, the study of national legislation and international legal regulation of international flights provides an opportunity to identify commonalities and differences and understand at what stage of the flight state legal regulation ceases to operate, and international norms are gaining strength.

The norms of international air law regulate the relations of states regarding the implementation of international flights by their aircraft, which should be understood as flights through the airspace over the territory of more than one state. From the point of view of 
law, the sphere of international law covers two levels: 1) legal regulation of international flights in the airspace of a number of states; 2) legal regulation of flights in international airspace. Each state independently determines the procedure for admission of foreign aircraft to its airspace. Such a permit system is the basis of the legal regime of the airspace of all states today, which is mandatory for both scheduled and non-scheduled international flights.

Note that no differences were found. The article also reveals the features of aviation and characterizes its types, which include civil and state aviation. The author also examined the problems existing in the legislation of Ukraine in the field of safety of international flights and suggested possible solutions.

Key words: international flights, airspace, safety of international flights, legal regime of international flights, Air Code of Ukraine.

DOI: 10.36695/2219-5521.2.2020.99

UDC 347.9

\section{S. SMIRNOVA}

Sofia Smirnova, Postgraduate student at London School of Economics (LSE) completing MSc in Human Rights and Politics*

ORCID: $0000-0002-1500-3023$

\section{JUDICIAL REFORM AND THE FIGHT AGAINST CORRUPTION IN UKRAINE}

Problems to solve. Arguably, a free and independent judiciary is the basis for good governance within any society. It is an 'essential prerequisite for upholding the rule of law' (United Nations General Assembly, 2012:3), crucial for enforcement of policies and reforms introduced by the government. Furthermore, it is fundamental for determining and implementing appropriate and effective punishment for those who disregard said legislation. Thus, the lack of an independent judiciary in Ukraine has often been critiqued as the primary reason for insufficient anti-corruption enforcement.

Analysis and Literature review. Based on the results of the studies of Dubrovskiy, Giardullo, Kostanyan, Wilson and Zhernakov and theoretical principles, conclusions have been formulated to reflect the directions of the solution, albeit fragmentary, of the existing problems. Thus, remains the lesser-researched problem of the independence of the judicial system of Ukraine in the enforcement of anti-corruption reforms. This article will discuss the most significant reforms within the judiciary; the Supreme Court reboot, the establishment of the National Anti-Corruption Bureau of Ukraine and the High Anti-Corruption Court, and the reform of the High Qualification Commission of Judges.

Aims of the article. This article is an analysis of the state of scientific development of the problem and the causes of corruption, emphasising that scientists acknowledge the need to combat this phenomenon.

Content of the article. Firstly, the package of anti-corruption reforms introduced under Poroshenko involved the creation of new institutional bodies for the enforcement of reforms, attempting to fulfil the first and second aims set out by the government in 2014. This intended to establish mechanisms for legislation implementation, primarily seen through the re-establishment of the Supreme Court in 2014. The reforms restructured the court system 'from a four-tier system (involving first and second instance courts, high (specialised) appeals courts, and the Supreme Court) to a three-tier system (first and second instance courts, and the Supreme Court with specialised integrated courts of cassation)' (OSCE, 2017: 11). The merging of the cassation courts aimed to resolve 'potential disparities in jurisprudence between the courts within the new Supreme Court' (Ibid.). The announced objectives of the reform aimed to completely 'reboot and renew the highest judicial body' (AntAC, 2017) as part of a more general court clean-up. The reduction of four levels of justice to three, as well as the introduction of several digitalisation policies to improve transparency within the system hoped to progress reform. These changes led to over 2,000 judges voluntarily abandoning their positions between 2014 and 2017 (Dubrovskiy, 2018: 30) beginning the complete reconstruction of the judiciary. The introduction of the 'Electronic Court' system created a 'single judicial information and telecommunications systems' (Unian, 2017) to operate in court proceedings. Legal documentation was also digitalised, allowing it to be exchanged electronically, in line with new legislation (Accace, 2017). The benefits of this system improved transparency as documentation and records of court proceedings could now be accessed online, through the relevant court's automated systems, with binding electronic signatures from judges. Finally, the new platform allowed parties the ability 'to apply the procedural documents' (Ibid.) for a variety of other uses, such as 'enquire about open appeal proceedings, obtain information about bankruptcy and pay court fees online' (Ibid.).

However, Dubrovskiy (2018: 30) does not believe that these changes have led to a significant 'rebuilding of the judiciary' due to significant failures within the composition of the new Supreme Court. The appointed judges fall 'short of what civil society' (Ibid.) hoped for in 2014, with ' 80 per cent of the appointees having previously served' (Ibid.) within the court system. This meant progressive constitutional change was met with a lack of enforcement mechanisms. In the absence of significant change in the composition of the new court, its so-called reboot seemed redundant, with little indication of progress. This exemplifies the most significant problems within judicial reform. Despite the constitutional changes, the government has yet to establish detailed procedural legislation on the implementation of these changes.

(C) S. Smirnova, 2020

* Софія Матвї̈вна Смірнова, студентка магістратури факультету прав людини та політики Школи економіки Лондона (LSE) 